\title{
Fluvalinate treatment of queen and worker honey bees (Apis mellifera $L$ ) and effects on subsequent mortality, queen acceptance and supersedure
}

\author{
JS Pettis ${ }^{1 *}$, WT Wilson ${ }^{1,}$ H Shimanuki 2, PD Teel 3 \\ 1 USDA, ARS, Honey Bee Research Unit, 2413 East Highway 83, Weslaco, TX 78596; \\ 2 USDA, ARS, Beneficial Insects Laboratory, Bldg 476, BARC-East, Beltsville, MD 20705; \\ ${ }^{3}$ Dept of Entomology, Texas A and M University, College Station, TX 77843, USA
}

(Received 13 March 1989; accepted 4 December 1990)

\begin{abstract}
Summary - Three experiments were conducted on queen and worker honey bees (Apis mellifera L) to assess effects of treatment with fluvalinate impregnated (Apistan $\left.{ }^{\circledR}\right)$ strips. A 5-d treatment of worker bees (weighing $1.4 \mathrm{~kg}$ per group) in screen packages with a fluvalinate strip ( $2.5 \% \mathrm{a} \mathrm{i,} 2.5 \mathrm{x}$ $13 \mathrm{~cm}$ ) did not increase mortality. Overwintered laying queens $(n=30)$, and newly mated queens $(n=60)$ were treated in Benton mailing cages for $5 \mathrm{~d}$ with fluvalinate (Apistan Queen Tabs, $1 \%$ a i, $2.5 \times 1.3 \mathrm{~cm}$ ). All queen mortality occurred on $\mathrm{d} 4$ and 5 of the treatment period, which is beyond the recommended 3-d-treatment. Neither group of treated queens exhibited a significant increase in mortality. However, attendant worker bees in the second trial exhibited a significant increase in mortality during treatment. No differences were observed in colony acceptance of queens, brood viability, or supersedure rates at 2 and 6 months post-exposure.
\end{abstract}

Apis mellifera / acaricide / fluvalinate / side-effect / mortality

\section{INTRODUCTION}

Honey bees infested with the parasitic mite Varroa jacobsoni (Oudemans) pose regulatory problems which may cause restrictions on the movement of bees. Many North American beekeepers rely on buying package bees and queens to maintain their operations. Canada and Mexico have banned importation of bees from the United States because of Varroa. In order to allow bees to move from infested areas to uninfested areas and to slow the spread of parasitic mites, treatments to rid the bees of mites before or during shipment have been sought.

The relative low toxicity to honey bees of fluvalinate has been demonstrated by several researchers (Stoner et al, 1984; Taylor et al, 1987; Borneck 1988; Henderson, 1988; Waller et al, 1988). Colony treatments to control $V$ jacobsoni with fluvalinate have also been favorable (Borneck and Merle, 1987, 1989; Koeniger

\footnotetext{
* Correspondence and reprints
} 
and Chmielewski, 1988; Lubinevski et al, 1988; Ruijter and Van Den Eijnde, 1989). Queen mailing cages present a unique treatment problem of exposing a limited number of bees and a queen to a toxic substance in a confined environment. Herbert et al (1988a) tested amitraz, fluvalinate and cymiazole and found the $1 \%$ a $i$ fluvalinate strip (Apistan $\left.{ }^{\circledR}\right)^{\star}$ to be effective against $V$ jacobsoni and also of low toxicity to worker bees during a 3-d treatment period in small cages. Toxicity to workers of $2.5-10 \%$ fluvalinate, however, was deemed objectionable in the confined environment of the test cages (Herbert et al, 1988 a). Treatment of worker bees with $2.5 \%$ fluvalinate in mailing packages has also shown promise (Herbert et al, 1988b; Witherell and Herbert, 1988).

USDA-APHIS briefly set up a US quarantine on movement of bees with Varroa; after fluvalinate treatment, however, bees could move from Varroa-infested to noninfested areas. Although the efficacy of fluvalinate against $V$ jacobsoni has been demonstrated, the effects on treated queens and workers in the absence of Varroa needs further testing.

The current studies were undertaken to examine the following: (1), worker mortality after treatment in a screen wire mailing package (1.4 kg per worker group) with a fluvalinate impregnated strip $(2.5 \% \mathrm{a}$ i); and (2), effect of treatment with a $1 \%$ fluvalinate strip on queen mortality, brood viability, and colony acceptance and supersedure rates of treated queens.

\section{MATERIALS AND METHODS}

All experiments were carried out on bees of predominately Italian stock near Weslaco, TX,
USA. Bees were free of Varroa sp based on alcohol washes of 500 bees per colony. All fluvalinate strips were manufactured by Zoecon Corporation.

\section{Worker mortality}

To test worker longevity after exposure to fluvalinate, two $1.4 \mathrm{~kg}$ worker packages were shaken from each of 5 strong colonies in February 1988. One package from each pair was fitted with a $2.5 \times 13 \mathrm{~cm}$ strip of $2.5 \%$ (a i) fluvalinate suspended under the queen cage. The companion cage contained no strip (untreated). All packages were supplied with $50 \%$ sucrose solution (vol:vol) and a caged queen. Packages were held for $5 \mathrm{~d}$ at $25 \pm 2{ }^{\circ} \mathrm{C}$ (mean $\pm \mathrm{sd}$ ). Mortality counts were taken from the cage floor after $5 \mathrm{~d}$. From each package, 3 subsamples of $67 \pm 13$ bees were placed in wooden cages $(7.5 \times 13 \times$ $4 \mathrm{~cm}$ ) (Kulincevic and Rothenbuhler 1973). Cages were held in an incubator at $30 \pm 1{ }^{\circ} \mathrm{C}$ and supplied with $50 \%$ sucrose solution and water. Daily mortality counts were recorded for $24 \mathrm{~d}$. Mortality rates were compared by a paired $t$-test.

\section{Overwintered laying queens}

Thirty overwintered laying queens were removed from active colonies in February 1988. A queen and 7 attendant worker bees were placed in a Benton mailing cage $(3 \times 8 \times 2 \mathrm{~cm})$. Each cage contained queen candy and either an Apistan Queen $\operatorname{Tab}^{\circledR}$ (1\% a i fluvalinate strip, $2.5 \times$ $1.3 \mathrm{~cm}$ ) stapled under the screen or no strip (untreated). Cages were held at $25 \pm 2{ }^{\circ} \mathrm{C}$ for $5 \mathrm{~d}$ and mortality was recorded daily. The 5-d treatment period was selected because queens being treated in transit may be exposed for longer than the 3-d label recommendation.

To examine acceptance rates of treated queens, two 3-frame nuclei were split from each of 15 strong colonies in February 1988. Nuclei were left queenless for $1 \mathrm{~d}$ before queens were introduced in mailing cages. One treated and 1 untreated queen was introduced into each pair

\footnotetext{
* Fluvalinate (Apistan $\left.{ }^{\otimes}\right)$ Zoecon, Inc, Dallas, Texas, USA : Mention of a proprietary product does not constitute a recommendation by the USDA, nor does it imply registration under FIFRA as amended.
} 
of nuclei. Queen cages were inverted on the top bars and inspected $2 \mathrm{~d}$ later for queen release. Nuclei were examined on the twelfth day for queen acceptance and egg production. Additionally, 100 cells containing eggs were marked to assess brood viability (Harbo and Szabo, 1984). Sixteen d later the 100 cells were examined and those reaching the late pupal stage were recorded as viable.

\section{Newly mated queens}

A second trial of queen acceptance was conducted in May 1988 with 60 newly mated queens from a commercial queen breeder. Evaluation methods followed the above experiment with the following exceptions: 1) both treated and untreated queens were shipped by mail for $2 \mathrm{~d}$ and then held at $25 \pm 2{ }^{\circ} \mathrm{C}$ for the last $3 \mathrm{~d}$ of the treatment period; 2), thirty double brood chamber hives were split equally (bees and brood), resulting in 60 paired colonies; 3 ), colonies were relocated to 2 new apiaries and left queenless for $1 \mathrm{~d}$ before introduction of the test queens; 4), after acceptance of queens, colonies were examined at 2 and 6 -month intervals to assess queen failures. Differences in queen and worker losses were analyzed using Fisher's exact test (Steel and Torrie, 1980).

\section{RESULTS}

\section{Worker mortality}

The number of dead bees per cage after 5 $d$ was not significantly different between treated $(68 \pm 21)$, and untreated $(81 \pm 12)$ groups ( $t=1.94,4 \mathrm{df}, P>0.05$ ). Mortality over the 24- $d$ period differed between the treated $(51 \pm 15)$, and untreated $(63 \pm 12)$ groups $(t=2.45,4 \mathrm{df}, P<0.05)$.

\section{Overwintered laying queens}

During the 5-d treatment 8 workers and 3 queens died in the 15 cages of the treated groups versus 2 workers and 1 queen in the 15 untreated cages (table 1). Only one

Table I. Effects on overwintered laying queens and newly mated queens exposed to a $1 \%$ fluvalinate impregnated strip, Apistan Queen Tabs ${ }^{\boxplus}$, in Benton mailing cages for $5 \mathrm{~d}$. Following treatment, queens were introduced into colonies and monitored.

\begin{tabular}{|c|c|c|c|c|c|c|}
\hline & \multirow[t]{2}{*}{$\begin{array}{l}\text { Mortality } \\
\text { after } 5 d\end{array}$} & & \multirow[t]{2}{*}{$\begin{array}{c}\text { Queens } \\
\text { not accepted }\end{array}$} & \multicolumn{2}{|c|}{$\begin{array}{c}\text { Queen failures } \\
\text { (\# failures } / n)\end{array}$} & \multirow[t]{2}{*}{$\begin{array}{c}\text { Total } \\
\text { queen losses }\end{array}$} \\
\hline & & & & 2 mo & $6 m o$ & \\
\hline & \multicolumn{6}{|c|}{ Overwintered laying queens } \\
\hline $\begin{array}{l}\text { Untreated } \\
(n=15)\end{array}$ & 1 & & 0 & - & - & 1 \\
\hline \multirow{2}{*}{$\begin{array}{l}\text { Treated } \\
(n=15)\end{array}$} & 3 & & 1 & - & - & 4 \\
\hline & \multicolumn{5}{|c|}{ Newly mated queens } & \\
\hline $\begin{array}{l}\text { Untreated } \\
(n=30)\end{array}$ & 1 & \multirow[t]{2}{*}{$:$} & 3 & $2 / 26$ & $1 / 24$ & 7 \\
\hline $\begin{array}{l}\text { Treated } \\
(n=30)\end{array}$ & 2 & & 3 & $0 / 24$ & $3 / 24$ & 81 \\
\hline
\end{tabular}

\footnotetext{
1 One treated queen killed during colony manipulations.
} 
worker died in the first $3 \mathrm{~d}$ of treatment. The remaining worker mortality and all queen mortality occurred on d 4 and 5 . Total queen losses were not significantly higher in the treated group. Brood viability did not differ between treated ( $89 \pm 6 \%$ ) and untreated ( $84 \pm 9 \%$ ) groups.

\section{Newly mated queens}

During the 5-d treatment, 37 workers and 2 queens died in the 30 treated cages versus 6 workers and 1 queen in the 30 untreated cages (table I). Again mortality occurred predominantly on $d 4$ and 5 . In 4 cages all 7 workers died, and 2 of these cages also lost their queens. Worker mortality was significantly greater in the treated cages $(P<0.05)$. Total queen losses were not significantly different. Brood viability was $88 \pm 0.1 \%$ and $89 \pm 0.1 \%$ for the treated and untreated queens, respectively.

\section{DISCUSSION}

There were no deleterious effects of $2.5 \%$ fluvalinate on worker mortality after the 5-d treatment period. There are no known reasons for the treated cages to show lower mortality. Similarly, Herbert et al (1988a) found lower overall mortality in cages treated with two $2.5 \%$ fluvalinate strips than cages containing one strip.

The only observable effect of fluvalinate was during the actual treatment period which was $2 \mathrm{~d}$ longer than the 3-d label specification. All queen mortality, and $>95 \%$ of the worker mortality occurred during the last $2 \mathrm{~d}$ of treatment. Queens that survived the treatment period showed no differences in colony acceptance rates or brood viability. Also, queen failures at 2 and 6 months were not different with the newly mated queens tested.

In the second trial, worker mortality differed. Four of the 30 cages accounted for $75 \%$ of worker mortality and $100 \%$ of the queen mortality in the treated group. Septicemia or undetected pathogens could be confounding factors; however, no visible evidence of disease was noted, and no clumping of mortality was observed in the untreated group.

Mortality of attendant workers and queens in both trials occurred predominantly on $d 4$ and 5 of the treatment. Thus the recommended 3-d treatment period should not be exceeded to reduce adverse effects on queens. Following the 5-d treatment, no detrimental effects were observed in queen acceptance by the colony, brood viability, or longevity of the newly mated queens through a 6-month period.

\section{ACKNOWLEDGMENTS}

We thank $M$ Holmes, USDA-APHIS and B and $M$ Weaver, Navasota, Texas, for their help in providing queens. We thank J Landrum, Zoecon Corp for supplying Apistan ${ }^{\circledR}$ strips and for financial assitance. Additional thanks go to $L$ Alvarez for help with the manuscript, and N Buenrostro for assisting with colony manipulations. A Dietz, F Eischen, W Plapp, and two anonymous reviewers made helpful comments on the manuscript.

Résumé - Traitement des reines et des ouvrières d'abeilles (Apis mellifera $\mathrm{L}$ ) au fluvalinate : conséquences sur la mortalité, l'acceptation des reines et la supersédure. L'action du fluvalinate sur la reines et les ouvrières d'abeilles a été évaluée en l'absence du parasite Varroa jacobsoni. Des ouvrières, regroupées en paquets de $1,4 \mathrm{~kg}$ et placées dans des boîtes d'expédition grillagées ont été exposées à 
un ruban $(2,5 \times 13 \mathrm{~cm})$ imprégné de fluvalinate $(2,5 \%$ de substance active) pendant 5 j. Cinq paquets ont été traités, 5 autres ont servi de témoins. A la fin du traitement 3 échantillons de $67 \pm 13$ abeilles ont été prélevés dans chacun des 10 paquets. Ces abeilles ont été mises dans des cagettes $(7,5 \times 13 \times 4 \mathrm{~cm})$ avec de l'eau et du sirop à disposition. Leur mortalité, à la température de $30 \pm 1^{\circ} \mathrm{C}$, a été observée pendant $24 \mathrm{j}$ : il n'y a pas eu d'augmentation.

Pour tester l'action des rubans imprégnés de fluvalinate à $1 \%$ (Apistan Queen Tabs $\left.{ }^{(}\right)$sur les reines, 2 tests ont été faits. Trente reines pondeuses âgées de moins de 4 mois ont été retirées de leurs colonies et placées chacune dans une cage d'expédition en bois $(3 \times 8 \times 2 \mathrm{~cm})$ avec 7 ouvrières accompagnatrices. Dans 15 cages, un ruban d'Apistan a été introduit sous le grillage, les 15 autres n'ont pas été traitées. La mortalité a été relevée quotidiennement pendant les 5 j qu'a duré le traitement. Au bout de $5 \mathrm{j}$, les reines, toujours dans leur cage, ont été placées dans des nucléi orphelins; l'acceptation de la reine et sa ponte ont été observées 12 j plus tard. Le second test a porté sur 60 reines récemment accouplées et âgées de moins de 2 mois. Elles ont été traitées comme cidessus mais en outre, on les a examinées 2 mois et 6 mois après le traitement pour déterminer le taux de supersédure. La mortalité des reines traitées est survenue les $4^{e}$ et $5^{\mathrm{e}} \mathrm{j}$ du traitement mais n'était pas significativement différente de celle des reines non traitées. Dans le second test, les ouvrières accompagnatrices ont présenté une mortalité significativement accrue par rapport aux ouvrières non traitées. Cette mortalité accrue due au traitement peut être évitée en précisant dans la notice de limiter le traitement à $3 \mathrm{j}$. Aucune différence n'a été notée concernant l'acceptation des reines traitées, la viabilité du couvain ou le taux du supersédure à 2 et 6 mois après le traitement.

\section{Apis mellifera / acaricide / fluvalinate / effet non intentionnel / mortalité}

\section{Zusammenfassung - Fluvalinat- Behandlung von Königinnen und Arbeitsbienen: Effekte auf die nachfolgende Mortalität, Annahme der Königinnen und Umweislung. Die} Auswirkungen von Fluvalinat auf Königinnen und Arbeitsbienen wurden in Abwesenheit von Varroa jacobsoni geprüft. Arbeitsbienen wurden in GitterVersandkisten $(1,4 \mathrm{~kg}$ Bienen pro Paket) für fünf Tage einem Fluvalinatimprägnierten Streifen $(2,5 \%$ bei einer Streifengröße von $2,5 \times 13 \mathrm{~cm}$ ) ausgesetzt. Fünf Pakete wurden behandelt, fünf andere blieben unbehandelt. Nach den fünf Tagen Behandlungszeit wurden aus jedem der 10 Versandkisten drei Proben zu je $67 \pm 13$ Bienen in Laborkäfigen $(7,5 \times 13 \times 4 \mathrm{~cm})$ untergebracht und mit Zuckerlösung und Wasser versorgt. Bei einer Temperatur von $30 \pm 1{ }^{\circ} \mathrm{C}$ wurde die Mortalität dieser Bienen 24 Tage lang beobachtet.

Um die Effekte von mit $1 \%$ Fluvalinat imprägnierten Streifen (Apistan Queen Tabs ${ }^{\circledR}$ ) zu prüfen, wurden zwei Tests durchgeführt. 30 legende Jungköniginnen (weniger als vier Monate alt) wurden ihren Völkern entnommen und mit sieben Begleitbienen in Holz-Versandkäfige ( $3 \times 8$ $\times 2 \mathrm{~cm}$ ) gebracht. In 15 Käfigen wurde unter das Gitter ein Apistanstreifen gelegt, 15 Käfige blieben unbehandelt. Während der fünf Tage dauernden Behandlung wurde täglich die Mortalität bestimmt. Nach Abschluß der Behandlung wurden die Königinnen aus den Käfigen weisellosen Kernvölkern zugesetzt und 12 Tage später auf Annahme und Eiablage 
geprüft. Der zweite Test bestand aus 60 frisch begatteten Königinnen (Alter weniger als 2 Monate), die wie oben beschrieben behandelt wurden, aber mit zusätzlicher Überprüfung zwei und sechs Monate später zur Feststellung der Umweislungsrate.

Ergebnisse. Eine fünf Tage währende Behandlung von Kunstschwärmen $(1,4 \mathrm{~kg})$ in Versandkästen mit Fluvalinatimprägnierten Streifen (2,5\%) steigerte die Sterblichkeitsrate der Arbeiterinnen während einer Periode von 24 Tagen nicht. Die Mortalität der behandelten Königinnen beschränkte sich auf die Tage vier und fünf der Behandlungszeit, sie war aber nicht signifikant von der Sterblichkeit unbehandelter Königinnen verschieden. Die Begleitbienen im zweiten Versuch zeigten eine signifikant erhöhte Sterblichkeitsrate gegenüber unbehandelten Bienen. Eine erhöhte Sterblichkeitsrate infolge der Behandlung könnte dadurch vermieden werden, da $B$ in den Begleitvorschriften die Behandlung auf drei Tage begrenzt wird. Hinsichtlich der Annahme der behandelten Königinnen in den Völkern, der Lebensfähigkeit der Brut oder der Umweislungsrate wurden bei der Untersuchung zwei und sechs Monate nach der Behandlung keine Unterschiede festgestellt.

\section{Apis mellifera / Akarizide / Fluvalinat / Mortalität}

\section{REFERENCES}

Borneck R (1988) Fluvalinate, an interesting molecule against Varroa jacobsoni. In: Proc EC Experts' Meeting on Varroatosis/Bad Homburg, 15-17 October 1986 (Cavalloro R, ed) Balkema, Rotterdam, 223-229

Borneck R, Merle B (1989) New test for Varroa control with Apistan () (fluvalinate). In: Proc
EC-Experts' Group/Udine, Italy, 28-30 Nov 1988 (Cavalloro R, ed) Luxembourg, 315-330

Borneck R, Merle B (1987) Nouveaux essais de lutte antivarroa avec fluvalinate. Abstr 31 st Int Congr Apic Warsaw Apimondia, Bucharest, 351-352

Harbo JR, Szabo TI (1984) A comparison of instrumentally inseminated and naturally mated queens. J Apic Res 23(1) : 31-36

Henderson CE (1988) Test of control agents for Varroa jacobsoni in honey-bee packages. In: Africanized Honey Bees and Bee Mites (Needham et al, eds) Ellis Horwood Ltd, UK, 380-386

Herbert EW Jr, Witherell PC, Shimanuki H (1988a) Control of Varroa jacobsoni on honey bees in queen cages and small laboratory cages using amitraz, fluvalinate and Apito ${ }^{\circledR}$. Am Bee J 128(4), 289-292

Herbert EW Jr, Bruce WA. Shimanuki H (1988b) Control of Varroa jacobsoni on honey bees in packages using Apistan ${ }^{\circledR}$. Am Bee J 128(9), 615-616

Koeniger N, Chmielewski (1988) A new approach to chemotherapy of varroatosis. In: Proc EC Experts' Meeting on Varroatis/Bad Homburg, 15-17 October 1986 (Cavalloro R, ed) Balkema, Rotterdam, 231-236

Kulincevic JM, Rothenbuhler (1973) Laboratory and field measurements of hoarding behavior in the honeybee (Apis mellifera). J Apic Res $12,179-182$

Lubinevski $Y$, Stern $Y$, Slabezki $Y$, Lensky $Y$, Ben-Yossef H, Gerson U (1988) Control of Varroa jacobsoni and Tropilaelaps clarae mites using Mavrik ${ }^{\circledR}$ in Apis mellifera colonies under subtropical and tropical climates. $A m$ Bee J 128(1), 48-52

Ruijter A De, Van Den Eijnde J (1989) Field experiments to determine the efficacy of Api$\operatorname{stan}^{\circledR}$ on Varroa mites in bee colonies and the effects on spring development of treated colonies. In: Proc EC-Experts' Group/Udine, Italy, 28-30 Nov 1988 (Cavalloro R, ed) Luxembourg, 331-337

Steel RGD, Torrie JH (1980) Principles and Procedures of Statistics. McGraw Hill Inc, pp 633

Stoner A, Wilson WT, Moffett JO (1984) Effects of longterm feeding of low doses of fenvalerate or fluvalinate in sucrose syrup on honey 
bees Apis mellifera in standard-size field colonies. J Ga Entomol Soc 19(4), 490-498

Taylor KS, Waller GD, Crowder LA (1987) Impairment of a classifical conditioned response of the honey bee (Apis mellifera $L$ ) by sublethal doses of synthetic pyrethroid insecticides. Apidologie 18(3), 243-252

Waller GD, Estesen BJ, Buck NA, Taylor KS, Crowder LA (1988) Residual life and toxicity to honey bees (Hymenoptera, Apidae) of selected pyrethroid formulations applied to cotton in Arizona USA. $J$ Econ Entomol 81(4), 1022-1026

Witherell PC, Herbert EW, Jr (1988) Evaluation of several possible treatments to control Varroa mite Varroa jacobsoni (Oud) on honey bees in packages. Am Bee J128(6), 441-445 